\title{
A Study "To Assess the Level of Knowledge on Swine Flu Among Adults in Selected Area at Poonchery, Kanchipuram District, Tamilnadu
}

\author{
N.William Raj ${ }^{1}$, R.Bhuvaneshwari ${ }^{1}$, Shenbagapraba. $\mathbf{N}^{2}$ \\ ${ }^{1}$ III Year Student B.Sc Nursing, ${ }^{2}$ Assistant Professor, Department of Community Health Nursing, Chettiand College \\ of Nursing, Chettinad Academy of Research and Education, Kelambakkam, Kanchipuram District,
}

Tamilnadu, India

\begin{abstract}
The swine flu is a viral disease that is transmitted to humans, the swine flu is also known as pork flu virus belonging to the family Orthomyxoviridae which is endemic in population of pigs. A study to assess the knowledge on swine flu among adults in Poonchery, Kanchipuram District, Tamilnadu, India. The study was conducted with the aim to assess the knowledge on swine flu among the adults and to associate knowledge on swine flu with selected demographic variables between the age group of (18 years to 60 years). A study was conducted and the sample was consisted of a total of 50 adults. The tool used for this study was structured questionnaire.It results that $52 \%$ of them having Inadequate knowledge, $30 \%$ of them having moderate knowledge and $18 \%$ of them having Inadequate knowledge. The chi square value is 20.9862 $(\mathrm{P}>0.05) \mathrm{S}^{*}$, There is significant association between demographic variables.we have found that there is inadequate knowledge of adult population.
\end{abstract}

Key words : Assess, knowledge, swine flu, adult.

\section{Introduction}

The current influenza outbreak of swine flu is a result of an influenza virus species that infected pigs,then re-assort (swap genes) and the new virus emerging. Currently there are four main influenza type A virus sub types, but the most recent influenza virus from pigs causing the outbreak have been H1N1 viruses. This new virus that has emerged is a mixture of swine, human and avian influenza viruses. ${ }^{1}$

The swine flu is a viral disease that is transmitted to humans, the swine flu is also known as pork flu (any) virus belonging to the family Orthomyxoviridae which is endemic in population of pigs $^{2}$. These strain of viruses are known as swine influenza virus of SIV (the acronym in English of swine influenza virus have been classified into influenza virus $\mathrm{C}$ or are the subtypes of the genus influenza virus A (being the best known strain H1N1 isolated in Japan and Europe).Such genetic restructuring occurs regularly in nature and, at times, provides the virus with the capability of causing widespread disease in immunologic-ally populations. The virus can move swiftly across geographical borders to cause pandemics ${ }^{1}$.

\section{Statement of the Problem:}

A study to assess the level of knowledge on swine flu among adults in selected areas at Poonchery, Kanchipuram District, Tamilnadu.

\section{Objective of the Study:}

1. To assess the knowledge on swine flu among the adults.

2. To associate knowledge on swine flu with selected demographic variables.

\section{Research Methodology}

- Research Approach : Non experimental approach.

- Research Design : Descriptive research design

- $\quad$ Research Setting

: The study was conducted in the selected Community area Poonchery at Kanchipuram District,Tamilnadu 
- Population : The population for this study in all adults who are residing at poonchery village at Kanchipuram District.

- Sample Size $\quad$ :50 adults.

- Sampling Technique : Simple Random Technique.

\section{Results}

SECTION-A: Frequency and percentage distribution of demographic variables of adults in assess the level of knowledge on swine flu among adults in Poonchery.

Age(years)in which majority (38\%) were belongs to the age between $39-48$ years.(18\%) were in the age group of 49-60years.

Sex, in which majority $(60 \%)$ of the samples were female and $(40 \%)$ of samples were Male

Marital status, in which majority (58\%) of the samples were unmarried.(3\%) samples were divorced.
Educational status, in which majority $(34 \%)$ of the samples belongs to the high school $(10 \%)$ were in the graduate

Income, in which majority $(60 \%)$ of the samples were Rs.5,000-10,0001 (2\%)were in the >15,000rupees

Types of family, in which majority (54\%) of the samples werejoint family(46\%)were in the nuclear family

Source of Information in which majority (36) of the samples belongs to the sources of knowledge from media. $(14 \%)$ were in the television.

SECTION-B: Distribution of knowledge on the Swine Flu among adults in selected Village Poonchery.

The study finding revealed that the frequency distribution in the study shows that majority 52\% of them having Inadequate knowledge,30\% of them having moderate knowledge and $18 \%$ of them having Inadequate knowledge on Swine Flu among adults.

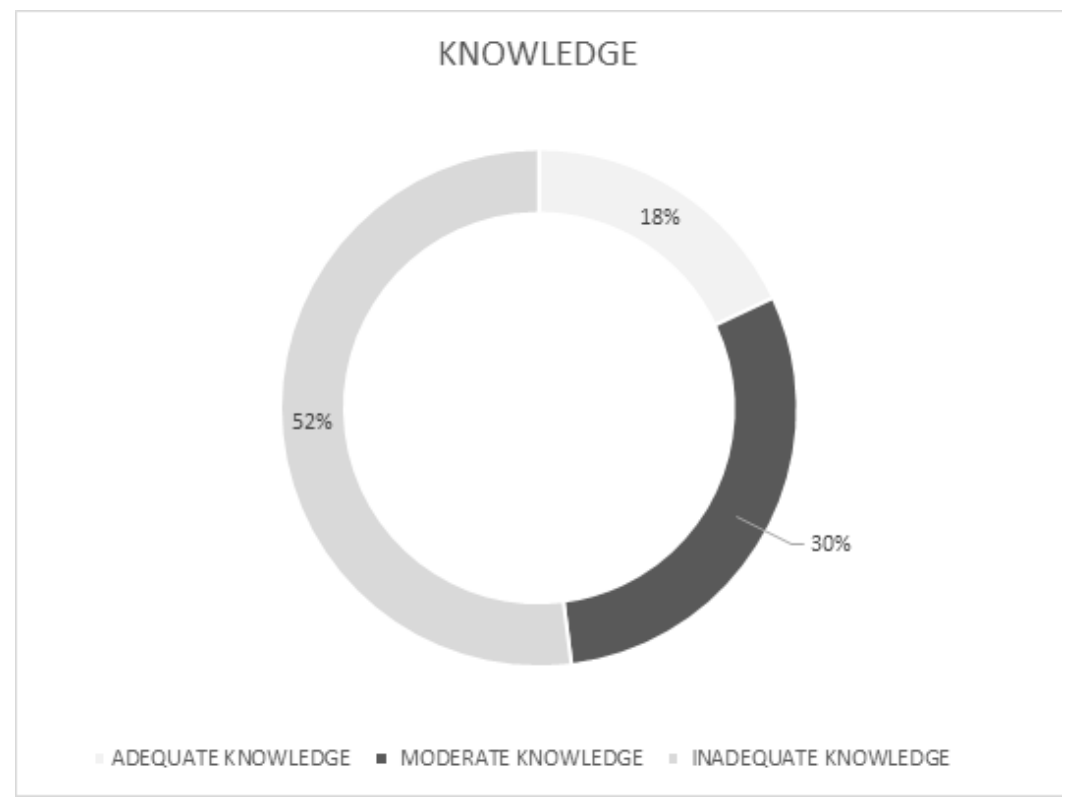

SECTION-C: Association on knowledge on Swine Flu among adults with demographic variables:

Regarding association there is significant association of factors influencing knowledge on Swine Flu among adults with demographic variables like age, Sex,Marital Status,Education status,Income,Type of family and sources of information.

\section{Summary}

The finding of the study indicated that the knowledge plays an important role in the health of the community. It is a suitable method of instruction for the community health nurses for disseminating health information regarding swine flu, management and prevention of the pandemic swine flu. Educational interventions are 
necessary to improve the knowledge. An improvement in the knowledge will lead to better practices, early identification of danger sign, initiation of appropriate treatment and prevention of the pandemic swine flu.

Source of Funding : Nil

Ethical Consuderation: Chettinad Academy of Research and Education,Institution Human Ethics Committee

\section{Conflict of Interest :Nil}

\section{References}

1. B.T.Basavanthappa, Textbook of Community Health Nursing, 2nd ed, 2018, Jaypee Publication,P. No 100 .
2. T.Baskarao, Textbook of Community Medicine, 12th ed, 2007,Jaypee Publications; P.No 124.

3. Black J. M Jacks, Textbook of Medical Surgical Nursing. London, 12th ed,2014,W.B. Saunders Company. P.No 241.

4. Francies, et al. Medical Surgical Nursing Foundations For Clinical Practice, 2nd ed, 1998. W. B. Saunders Company,P.No 284.

5. S. Kamalam, Textbook of Essentials of Community Health Nursing, $2^{\text {nd }}$ ed ,2008.Jaypee Publications,P. No 129 . 